Ege Tıp Dergisi / Ege Journal of Medicine 2019;58(2):181-183

\title{
Tekrarlayan akciğer enfeksiyonunun nadir bir nedeni: Jeune sendromu
}

\author{
A rare cause of recurrent pulmonary infection: Jeune syndrome \\ Çapan Konca@ Muhammed Nebi Çalışkan \\ Adıyaman Üniversitesi Tıp Fakültesi, Çocuk Sağlığı ve Hastalıkları Anabilim Dalı, Çocuk Yoğun Bakım \\ Bilim Dalı, Adıyaman, Türkiye
}

\section{Öz}

Otozomal resesif geçişli bir hastalık olan Jeune sendromu, birçok sistem tutulumu ile giden nadir bir iskelet displazisidir. Asfiktik torasik distrofi olarak da bilinen bu hastalıkta, solunum sıkıntısına yol açan çan şeklinde dar göğüs kafesi, kısa ekstremiteli cücelik ve pelvik kemik anomalileri en tipik muayene bulgularıdır. Tekrarlayan alt solunum yolu enfeksiyonu nedeniyle kliniğimize başvuran ve Jeune sendromu tanısı koyulan 7 aylık kız çocuk, nadir görülen bir hastalık olması nedeniyle sunulmuştur.

Anahtar Sözcükler: Asfiktik torasik displazi, Jeune sendromu, tekrarlayan pnömoni.

\begin{abstract}
Jeune syndrome, is a rare autosomal recessive skeletal dysplasia characterized by multisystem involvement. In this disease, otherwise called as "asphyxiating thoracic dystrophy", bell-shaped narrow thorax that leads to respiratory distress, short-limbed dwarfism, and typical pelvic abnormalities are the most common clinical signs. Herein we present a 7-month-old girl who admitted to our clinic because of recurrent lower respiratory tract infection and diagnosed as Jeune syndrome and we report the case due to its rarity.
\end{abstract}

Keywords: Asphyxiated thoracic dystrophy, Jeune syndrome, recurrent pneumonia.

\section{Giriş}

Jeune sendromu otozomal resesif geçişli çoklu organ tutulumu gösteren nadir bir iskelet displazisidir. Asfiktik torasik distrofi olarak ta bilinen bu hastalıkta, solunum sıkıntısına yol açan çan şeklinde dar göğüs kafesi, kısa ekstremiteli cücelik ve pelvik kemik anomalileri en sık görülen klinik özelliklerdir. Olguların çoğunluğu bebeklik döneminde akciğer hipoplazisi veya tekrarlayan akciğer enfeksiyonlarına bağlı solunum yetmezliğinden kaybedilirken; daha büyük yaştaki çocukların bir kısmı da böbrek, karaciğer ve pankreas yetmezliği gibi nedenlerle kaybedilmektedir. Ancak literatürde erişkin yaşa ulaşabilmiş az sayıda vaka bildirilmiştir (1). Jeune sendromuna hepatik ve biliyer fibrozis, pelvik anomaliler, polidaktili, retinal pigmentasyonlar ve dejenerasyonlar gibi klinik durumların eşlik edebileceği bildirilmiştir $(2,3)$. Hastalığın prognozunu göğüs deformitesinin ağırlığı belirlemektedir. Bu makalede tekrarlayan akciğer enfeksiyonu yakınması ile başvuran ve iskelet anomalileri olan

Yazışma Adresi: Çapan Konca

Adıyaman Üniversitesi Tıp Fakültesi, Çocuk Sağlığı ve Hastalıkları Anabilim Dalı, Çocuk Yoğun Bakım Bilim Dalı, Adıyaman, Türkiye

E-mail:dr.capan@hotmail.com

Makalenin Geliş Tarihi:07.12.2017 Kabul Tarihi: 25.01.2018 çocuklarda, nadir bir neden olarak Jeune sendromunun ayırıcı tanılar arasında düşünülmesi ve ailenin hastalık hakkında bilinçlendirilmesinin öneminin vurgulanması amaçlanmıştır.

\section{Olgu Sunumu}

Yedi aylık kız hasta öksürük, hırıltı, nefes almada zorluk ve ateş yakınmaları ile başvurdu. Mevcut yakınmalarla 5 gün önce dış merkeze başvuran ve ayaktan tedaviye yanıt alınmayan hasta kliniğimize sevk edilmişti. Yirmi beş yaşındaki anneden G2P2Y1 olarak sezaryen ile miadında $2550 \mathrm{~g}$ doğan hastamızın özgeçmişinde $2 \mathrm{kez}$ akciğer enfeksiyonu nedeni ile başka bir merkezde yatarak tedavi öyküsünün olduğu öğrenildi. Gebelik boyunca takipli olan hastaya doğum öncesinde ve doğumdan sonraki süreçte herhangi bir hastalık şüphesi olduğu söylenmediği ve göğüs kafesi ile ilgili herhangi bir inceleme de yapılmadığı ifade edildi. Soy geçmişte ebeveynlerin akraba olmadığı, ancak ilk gebelikten canlı doğan bebeğin ilk 24 saatte öldüğü söylendi.

Fizik muayenesinde, genel durumu iyi, bilinç açık, vücut sıcaklığı $36.7^{\circ} \mathrm{C}$, vücut ağırlığı $5800 \mathrm{~g}(<3 \mathrm{p})$, boyu 64 cm (3-10 p), baş çevresi $43 \mathrm{~cm}$ (10-25 p), göğüs çevresi/karın çevresi oranı 0.73 , kulaç mesafesi kısa ölçülen hastanın baş-pubis/pubis-topuk oranı 1.44, başpubis/boy oranı \%59 idi. Oksijen satürasyonu \%93, 
solunum sayısı 56/dk, nabzı 148/dk ve tansiyonu 95/50 $\mathrm{mmHg}$ bulundu. İnspeksiyonda dar, uzun ve çan şeklinde göğüs kafesi, interkostal retraksiyonları, üst ve alt ekstremitelerde rizomelik kısalık ve batın distansiyonu önemli fizik muayene bulguları idi (Şekil-1a). Dinlemekle akciğerlerde yaygın bilateral krepitan raller duyuldu. Diğer sistem bulguları normaldi.

Laboratuvar tetkiklerinde, hemoglobin $12.4 \mathrm{~g} / \mathrm{dL}$, hematokrit \%33.7, lökosit $11.200 / \mathrm{mm}^{3}$, trombosit $351.000 / \mathrm{mm}^{3}$ bulundu. Karaciğer, böbrek fonksiyon testleri, kalsiyum ve diğer serum elektrolitleri, bilirübin, total protein, albümin düzeyleri, tam idrar tetkiki, tiroid fonksiyon testleri, C-reaktif protein, protrombin zamanı, parsiyel tromboplastin zamanı, serum immünglobulin ( $A$ $G, M)$ düzeyleri, arteriyel kan gazları, paratiroid hormunu ve 25-hidroksi $\mathrm{D}$ vitamini düzeyleri normal bulundu. Radyografik incelemede akciğer grafisinde dar göğüs kafesi, kısa kostalar ve solda daha belirgin olmak üzere çift taraflı pnömonik infiltrasyon olduğu görüldü. Ön-arka pelvis grafisinde hipoplastik iliyak kanatlar, sivri sakrosiyatik çentiklerle birlikte sığlaşmış asetabular açılar ve inceleme alanına giren uzun kemiklerde belirgin olarak kısalık ve metafizer genişlik olduğu görüldü (Şekil-1b).

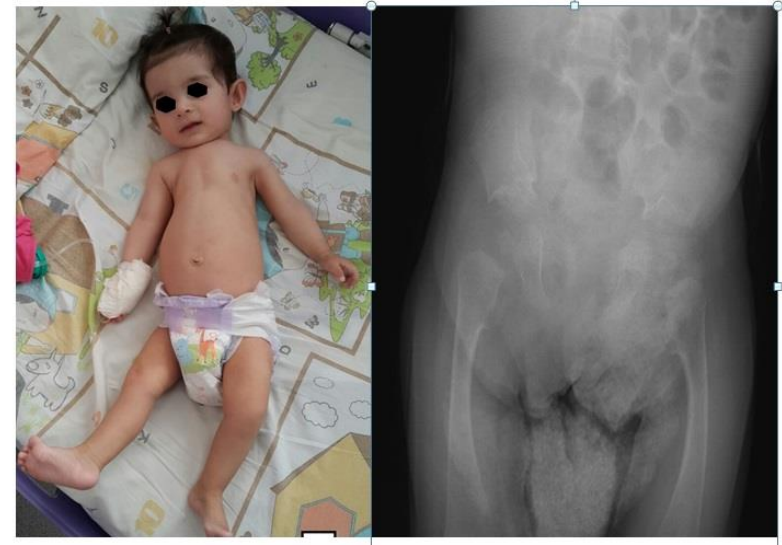

Şekil-1. a. Hastanın genel görünümünde dar, uzun ve çan şeklinde göğüs kafesi, uzuvların proksimal kısımlarında kısalık ve batında distansiyon izlenmekte, b. Pelvis grafisinde hipoplastik iliyak kanatlar ve inceleme alanına giren uzun kemiklerde belirgin olarak kısalık ve metafizer genişlik mevcut.

Transfontanel ultrasonografi (USG) ve ekokardiyografi normal bulundu. Ancak batın USG incelemesinde sol böbrekte 2. derece hidronefroz saptandı.

Mevcut bulgularla hastaya Jeune sendromu tanısı konuldu. Akciğer enfeksiyonu için seftriakson ve klaritromisin tedavileri başlandı. Göğüs cerrahi konsültasyonu sonucunda cerrahi endikasyon olmadığı belirtildi. Tedavinin 11. gününde genel durumu düzelen hasta, hidronefrozun takibi için Çocuk Nefroloji polikliniğine ve genetik danışmanlık almak için Tıbbi Genetik anabilim dalına yönlendirilerek taburcu edildi. Aileye sendrom hakkında bilgi verildi.
Hastanın yasal vasisinden tıbbi verilerinin yayınlanabileceğine ilişkin yazılı onam belgesi alındı.

\section{Tartışma}

Jeune sendromu, ilk kez 1954 yılında dar göğüs duvarına sahip, multipl kıkırdak anomalisi bulunan ve erken perinatal dönemde solunum yetmezliğinden kaybedilen bir yenidoğanda tanımlanmış otozomal resesif geçişli bir hastalıktır (4). Bu hastalar çoğunlukla hipoplastik kaburgalara bağlı küçük ve hareketsiz göğüs kafesinin yol açtığı solunum yetmezliğine bağlı olarak yenidoğan döneminde kaybedilmektedir. Olgumuzda olduğu gibi, nadiren yenidoğan döneminde solunum sistemi yakınmaları olmadan süt çocukluğu döneminde tekrarlayan solunum sistem yakınmaları ile de hastanelere başvurular yapılabilmektedir. Bu hastalarda bronşiyal gelişim normal iken alveolar gelişim bozuktur ve çoğu hastada pulmoner hipoplazi eşlik etmektedir (5). Yaşamın ilk yılında en temel yaşamsal problem solunum sistemi hastalıklarıdır. Bu dönemi atlatabilen çocuklarda solunum problemleri yaş arttıkça azalmasına rağmen; sonradan ortaya çıkan ilerleyici böbrek ve karaciğer hastalıkları prognozu belirleyen en önemli faktörler olmaktadır $(1,6)$. Hastamızda erken süt çocukluğu döneminde başlayan tekrarlayan akciğer hastalıkları, kısa uzuvlar (özellikle proksimal kemiklerde) ve küçük göğüs kafesi en önemli klinik özellikler idi.

$\mathrm{Bu}$ hastalarda karaciğer ve böbrek tutulumu dışında, pankreas tutulumu, göz tutulumu, parmak sayı ve yapı anomalileri, kardiyak tutulum ve korpus kallozum agenezisi gibi patolojiler eşlik edebileceği için bu açılardan ayrıntılı inceleme yapılması önerilmiştir (7). Biz de hastamızda yaptığımız incelemede sol böbrekte 2 . derece hidronefroz saptadık.

Çan şeklinde ve dar göğüs kafesi, düzleşmiş, kısa ve kalınlaşmış kaburgalar, kostokondral kıkırdaklarda belirginleşme, geniş metafizler, kısa ekstremiteler, hipoplastik iliyak kanatlar ve daraltılmış asetabular açılar hastalık için karakteristik radyolojik bulgulardır (8). Hastamızda belirtilen radyolojik bulguların neredeyse tümü mevcuttu.

Henüz hastalığın prenatal tanısında etkin olarak kullanılabilen herhangi bir genetik veya biyokimyasal belirteç yoktur. Bu dönemde en kullanışlı tanı yöntemi olan USG, risk durumuna göre 14 ile 16. gebelik haftaları arasında yapılabilmektedir (6). Ayrıca, 18. haftadan sonra yapılan USG'de göğüs çevresi/karın çevresi oranının 0.85 'ten küçük olması önemli bir belirteç kabul edilmektedir (9). Hastalığın doğum sonrası tanısı genelde tipik klinik ve radyolojik özelliklere dayandırılmaktadır. Biz de hastamıza tipik klinik ve radyolojik bulgular eşliğinde Jeune sendromu tanısı koyduk.

Ellis-van Creveld sendromu, Barnes sendromu ve kısakosta polidaktili sendromu gibi durumlar ayırıcı tanılar arasında akılda bulundurulmalıdır. Birçok ortak bulgu 
olmasına rağmen, polidaktili, kardiyak patolojiler, laringeal stenoz, anal atrezi, yarık damak/dudak anomalisi gibi birçok klinik özellikler ile ayırıcı tanıya gidilmektedir. Hastamızda dar göğüs kafesine eşlik edebilen bu bulguların hiçbiri olmadığı için Jeune sendromu düşünüldü.

Hastalığın tedavisinde medikal ve cerrahi tedavi seçenekleri mevcut olmasına rağmen; genelde destek tedavilerinin baskın olduğu medikal tedaviler tercih edilmektedir. Cerrahi olarak sternum uzunlamasına açılarak ve otolog ve sentetik greftlerle aralıklı olarak tespit edilerek iki hemitoraks arası mesafe genişletilmeye çalışılmaktadır (10). Ancak cerrahi müdahalelerin başarısı ile ilgili uzun dönem veriler mevcut değildir. Destek tedavisi olarak, enfeksiyonlarla mücadele, gerektiğinde mekanik ventilasyon, gerektiğinde nazogastrik sonda veya gastrostomi ile besleme ve böbrek yetmezliğinde renal transplantasyon ve diyaliz yapılabilir. Ayrıca, bu ailelere mutlaka genetik danışma verilmelidir. Biz hastamızda medikal tedavi uygulayıp, genetik danışma verdik. Sonuç olarak; tekrarlayan solunum yolu enfeksiyonu, boy kısalığı ve göğüs deformitesi ile başvuran olgularda Jeune sendromu da ayırıcı tanıda akılda tutulmalıdır ve ailelerin genetik danışmanlık alması sağlanmalıdır.

\section{Kaynaklar}

1. Yiyit N, Yıldızhan A, Candaş FH, Görür R, Işııtmangil T. Yetişkin yaşa ulaşmış Jeune sendromu olgusu. Gülhane Tıp Derg 2015;57(2): 188-9

2. Karjoo M, Koop CE, Cornfield D, Holtzappla PG. Pancreatic exocrine enzyme deficiency associated with asphyxiating thoracic dystrophy. Arch Dis Child 1973; 48(2): 143-6.

3. Wilson DJ, Weleber RG, Beals RK. Retinal dystrophy in Jeune's syndrome. Arch Ophtalmol 1987; 105(5): 651-7.

4. Jeune M, Beraud C. Carron R. Dystrophie thoracique asphyxiante de caractère familial. Arc Fr Pediatr 1955;12(8): 886-91.

5. Williams AJ, Vawter G, Reid LM. Lung structure in asphyxiating thoracic dystrophy. Arch Pathol Lab Med 1984; 108(8): 658-61.

6. De Vries J, Yntema JL, Van Die CE, et al. Jeune syndrome:description of 13 cases and a proposal for follow-up protocol. Eur J Pediatr 2010;169(1):77-88.

7. Uçar Ş, Zorlu P, Şahin G,Yıldırım M, Uşak E. Jeune sendromu (asfiktik torasik displazi): Olgu sunumu. Tüberküloz ve Toraks Dergisi 2009; 57(4): 413-6.

8. Oberklaid R, Danks DM, Mayne V, Campbell P. Asphyxiating thoracic dysplasia. Clinical, radiological, and pathological information on 10 patients. Arch Dis Child 1977; 52(10): 758-65.

9. den Hollander NS, Robben SG, Hoogeboom AJ, Niermeijer MF, Wladimiroff JW. Early prenatal sonographic diagnosis and follow-up of Jeune syndrome. Ultrasound Obstet Gynecol 2001;18(4):378-83.

10. Sharoni E, Erez E, Chorev G, Dagan O, Vidne BA. Chest reconstruction in asphyxiating thoracic dystrophy. J Pediatr Surg 1998; 33(10): 1578-81. 